\title{
PENGEMBANGAN MOBILE LEARNING MATA PELAJARAN BIOLOGI BERBASIS SCIENCE, TECHNOLOGY, AND SOCIETY (STS) UNTUK KELAS X SMAN 1 KAMPAK TRENGGALEK
}

\author{
Rinasih, Saida Ulfa, Sulthoni \\ Teknologi Pembelajaran Pascasarjana Universitas Negeri Malang \\ E-mail: rinasihbe1@gmail.com
}

\begin{abstract}
Abstrak: Pengembangan mobile learning mata pelajaran biologi berbasis Science, Technology and Society (STS) menawarkan solusi akibat keterbatasan waktu tanpa menghilangkan keterampilan proses sains dalam pembelajaran. Tujuan pengembangan adalah menghasilkan produk mobile learning yang valid dan efektif untuk digunakan dalam pembelajaran. Metode pengembangan ini menggunakan model ASSURE, tahapannya meliputi analyze learner; state objectives; select methods, media and materials, utilize media and materials; require learner participation; evaluate and revise. Instrumen penelitian menggunakan angket tanggapan dari ahli materi, ahli media, uji perorangan, uji kelompok kecil, uji lapangan, dan rubrik penilaian. Berdasarkan analisis data hasil penelitian mobile learning mata pelajaran biologi berbasis STS dinyatakan valid dan efektif untuk digunakan dalam pembelajaran serta domain-domain STS telah tercapai.
\end{abstract}

Kata Kunci: mobile learning, STS, Biologi

\section{PENDAHULUAN}

Pembelajaran sains, pada hakikatnya bukan sekedar pengetahuan yang bersifat ilmiah, melainkan memuat keterampilan proses dan dimensi yang terfokus pada karakteristik nilai dan watak ilmiah. Keterampilan proses sains meliputi cara-cara memperoleh, mengelaborasi dan mengaplikasikan pengetahuan yang mencakup cara kerja, cara berpikir, cara memecahkan masalah, dan cara bersikap.Sebagai bagian dari sains, pembelajaran biologi harus berubah, bukan hanya sekedar mentransfer pengetahuan (transfer of knowledge) saja. Namun, siswa hendaknya dibekali dengan keterampilan untuk menerapkan pengetahuannya mengenai konsep biologi untuk pemecahan masalah dalam kehidupan sehari-hari. Dengan demikian, pembelajaran biologi semestinya dapat dikaitkan dengan pengalaman keseharian siswa. Sebagai bagian dari anggota masyarakat, siswa dapat dibiasakan untuk menemukan masalah dalam lingkungan lokal maupun secara global, dan merumuskan solusi ilmiah dengan mengaitkan dengan konsep sains yang sedang dipelajarinya.

Tantangan dalam pembelajaran sains adalah menyelaraskan kemajuan ilmu pengetahuan, teknologi, serta dapat mengantisipasi masalah-masalah sosial yang timbul akibat perkembangan sains dan teknologi. Untuk itu pembelajaran sains perlu dikaitkan dengan aspek teknologi dan masyarakat. Pembelajaran yang mengkaitkan sains dengan teknologi dan masyarakat, serta memberdayakan keterampilan proses sains dikenal dengan pembelajaran Science, Technology and Society (STS). Sebagaimana diungkapkan oleh Poedjiadi (2010: 99) model STS 
artinya mendayagunakan teknologi sebagai pendukung antara sains dan masyarakat.

Istilah Science, Technology and Society pada mulanya dikemukakan oleh John Ziman dalam bukunya Teaching and Learning about Science and Society. Ziman (1980) mengidentifikasi STS sebagai suatu pendekatan kurikulum yang dirancang untuk membuat konsep dan proses yang ditemukan dalam program IPA dan IPS yang relevan dengan kehidupan siswa. NTSA (National Science Teacher Association) mendefinisikan STS sebagai pengajaran dan pembelajaran sains dalam konteks pengalaman manusia. Ini menekankan pentingnya teknologi dan ilmu pengetahuan, memasukkan perkembangan teknologi dalam kurikulum dan menyediakan topik yang sesuai untuk semua siswa (Yager, 1992).

Hasil penelitian yang dilakukan oleh Akcay dan Yager (2010) menunjukkan siswa yang belajar dengan menggunakan model STS memiliki kelebihan: (1) mampu menguasai banyak konsep-konsep ilmu dasar; (2) pemahaman dan penggunaan keterampilan proses sains mereka lebih tinggi; (3) memiliki keterampilan dan kreativitas yang lebih tinggi; (4) memiliki pengembangan sikap yang lebih positif terhadap sains; dan (5) mampu menerapkan konsep-konsep ilmu dasar pada situasi baru dengan lebih baik. Hasil penelitian ini menunjukkan lima domain yang dikembangkan melalui STS yaitu konsep, proses, kreativitas, sikap dan aplikasi. Dass dalam King (2009) menyebutkan empat fase STS. Keempat fase yang terangkum dalam sintaks STS adalah (1) tahap invitasi, (2) tahap eksplorasi, (3) tahap mengusulkan penjelasan dan solusi, dan (4) tahap penentuan tindakan.

Fenomena di lapangan menunjukkan menemukan fakta bahwa siswa belum memiliki keterampilan proses sains. Hal ini tercermin dari kecenderungan siswa yang pasif dalam pembelajaran. Siswa belum bisa memposisikan dirinya sebagai subyek pembelajaran. Siswa belum termotivasi untuk terlibat secara aktif dan mengeksplorasi wawasannya. Guru telah berupaya memfasilitasi siswa dengan penggunaan media video, media presentasi, dan buku penunjang atau buku paket. Namun dalam penggunaan media-media tersebut muncul berbagai kendala.

Dalam penggunaan media video dan media presentasi, membutuhkan alat bantu LCD proyektor. Ketersedian LCD di sekolah tersebut sangat terbatas, sehingga penggunaanya harus bergantian dengan kelas lain. Saat LCD tidak ada, maka media ini tidak dapat ditampilkan. Kelemahan lain yang muncul dalam media presentasi yaitu isi bahan ajar yang digunakan belum menampilkan penggambaran ilustrasi objek nyata dalam materi biologi yang mendiskripsikan capaian kompetensi yang harus dimiliki siswa di akhir belajar. Sedangkan untuk buku paket, tidak semua siswa mempunyai buku paket. Kesamaan dari tiga media ini adalah materi belum dapat dimiliki oleh siswa sendiri. Untuk itu dibutuhkan sebuah media yang dapat digunakan siswa untuk belajar kapan saja.

Di sisi lain SMA telah menggunakan sistem belajar kredit semester (sks) sehingga dalam satu semester memuat lebih banyak materi yang harus dipelajari oleh siswa dalam waktu terbatas. Untuk itu sangat urgen dibutuhkan sebuah media yang mendukung sistem belajar mandiri yang di dalamnya memuat komponen lengkap pembelajaran. Salah satu karakteristik media yang mampu memberikan jawaban dari kebutuhankebutuhan tersebut adalah mobile learning. "Mobile technologies are revolutionizing education, transforming the traditional ways of learning and teaching into "anytime", and particulary "anyplace" education" (Ulfa, 2013: 2). Dengan mobile learning siswa dapat mengakses konten pembelajaran langsung dari smartphone masing-masing kapanpun dan dimanapun serta dapat mempelajari kembali materi yang kurang dikuasai. 
Teknologi mobile semakin meluas dengan kombinasi peningkatan kemampuan teknologi, seperti akses internet, deteksi lokasi dan presentasi multimedia. Dukungan multimedia ini didasarkan pada ide bahwa pesan pembelajaran harus dirancang dan dibuat sejalan dengan bagaimana otak manusia itu bekerja. Manusia mempuyai dua sistem pemrosesan informasi, yaitu materi verbal dan materi visual. Penalaran multimedia yakni penyajian pesan dalam bentuk katakata dan gambar-gambar yang ditujukan untuk memanfaatkan kapasitas manusia sepenuhya (Mayer, 2009: 4). Pengertian multimedia menurut Gayeski dalam Munir (2013: 2) adalah kumpulan media berbasis komputer dan sistem komunikasi yang memiliki peran untuk membangun, menyimpan, menghantarkan, dan menerima informasi dalam bentuk teks, grafik, audio, video dan sebagainya.

Dalam pengembangan ini mobile learning dipadukan dengan model pembelajaran Science Technology and Society (STS). Mobile learning berbasis STS yakni organisasi pembelajaran dalam mobile learning mengikuti sintaks model pembelajaran STS. Dengan adanya media ini diharapkan dapat membantu siswa memahami materi ekosistem dan pencemaran lingkungan, karena siswa dapat mengakses konten pembelajaran langsung dari smartphone masing-masing serta dapat menjadi jembatan situasi dunia nyata di luar kelas yang menyangkut teknologi dan situasi sosial kemasyarakatan. Mobile learning mata pelajaran biologi berbasis STS mampu mengatasi keterbatasan waktu tanpa menghilangkan keterampilan proses sains.
Jenis penelitian yang dipilih adalah penelitian pengembangan dengan model pengembangan yang digunakan mengadopsi model ASSURE (Smaldino, 2004). Model ASSURE dipilih berdasarkan beberapa alasan yaitu: (1) menitikberatkan pada desain pembelajaran di kelas; (2) adaptif, mudah diterapkan; (3) sistematis, hubungan antar komponen teratur dan menyeluruh. ASSURE merupakan salah satu model Instructional System Design (ISD) yang terdiri dari enam langkah susuai dengan rumusan kata itu sendiri. Langkahlangkahnya meliputi: (1) Analyze learner; (2) State objectives; (3) Select methods, media and materials; (4) Utilize media and materials; (5) Require learner participation; dan (6) Evaluate and revise.

Desain uji coba dalam pengembangan ini melibatkan uji ahli dan uji pengguna. Uji ahli terdiri dari ahli materi dan ahli media. Sedangkan uji pengguna terdiri dari uji coba perorangan, uji coba kelompok kecil, dan uji coba lapangan. UJi coba perorangan terdiri dari 3 siswa, uji coba kelompok kecil terdiri dari 9 siswa, dan uji coba lapangan melibatkan 32 siswa kelas X SMAN 1 Kampak.

Jenis data diperoleh dari hasil
validasi terhadap produk yang dikembangkan berupa data kuantitatif dan kualitatif. Data kuantitatif berupa perhitungan rata-rata dan persentase yang diperoleh dari penskoran angket validasi ahli materi, ahli media, dan siswa serta skor tes hasil belajar. Sedangkan data kualitatif berupa komentar, saran, dan kritik yang diperoleh dari subjek uji coba untuk perbaikan produk.

HASIL DAN PEMBAHASAN

Hasil Penilaian Ahli Materi Pembelajaran

\section{METODE}

Pengembangan Mobile ..... -Rinasih- || 30 
Hasil analisis data penilaian ahli materi pembelajaran menunjukkan persentase sebesar 83,93\%. Produk pengembangan mobile learning mata pelajaran biologi berbasis STS termasuk kualifikasi sangat valid dan layak digunakan sebagai media dalam pelaksanaan pembelajaran di kelas. Revisi yang diakukan berdasarkan masukan ahli materi adalah menambah cakupan materi pada materi komponen penyusun ekosistem dan aliran energi dalam ekosistem.

\section{Hasil Penilaian Ahli Media Pembelajaran}

Hasil analisis data penilaian ahli media pembelajaran menunjukkan persentase sebesar 97,05\%. Produk pengembangan mobile learning mata pelajaran biologi berbasis STS termasuk kualifikasi sangat valid dan layak digunakan sebagai media dalam pelaksanaan pembelajaran di kelas. Revisi yang diakukan berdasarkan masukan ahli media adalah mencetak buku petunjuk penggunaan yang sebelumnya dalam bentuk soft file

\section{Hasil Penilaian Uji Coba Perorangan}

Hasil analisis data uji coba perorangan menunjukkan persentase sebesar $82,78 \%$. Produk pengembangan mobile learning mata pelajaran biologi berbasis STS termasuk kualifikasi sangat valid dan layak digunakan sebagai media dalam pelaksanaan pembelajaran di kelas.

\section{Hasil Penilaian Uji Coba Kelompok Kecil}

Hasil analisis data uji coba kelompok kecil menunjukkan persentase sebesar $82,22 \%$. Produk pengembangan mobile learning mata pelajaran biologi berbasis STS termasuk kualifikasi sangat valid dan layak digunakan sebagai media dalam pelaksanaan pembelajaran di kelas.

\section{Hasil Penilaian Uji Coba Lapangan}

Hasil analisis data uji coba lapangan menunjukkan persentase sebesar 86,19\%. Produk pengembangan mobile learning mata pelajaran biologi berbasis STS termasuk kualifikasi sangat valid dan layak digunakan sebagai media dalam pelaksanaan pembelajaran di kelas. Saran dari subyek uji coba kelas sebaiknya diskusi tidak dilakukan secara online karena ada beberapa wilayah yang tidak didukung dengan jaringan internet, serta tidak adanya kuota data bagi beberapa siswa. Kelemahan ini bukan termasuk dalam kelemahan produk, namun sangat bergantung pada demografi wilayah dan tingkat ekonomi pengguna. Dalam hal ini, upaya yang dilakukan oleh pengembang adalah melakukan diskusi kelas setelah diskusi online agar siswa-siswa yang belum mengikuti diskusi online tetap dapat memperoleh materi pembelajaran.

Tabel 1. Hasil Penilaian Persentasi Keseluruhan Subjek Uji Coba terhadap Produk Mobile Learning berbasis STS

\begin{tabular}{|c|c|c|c|c|c|}
\hline $\begin{array}{l}\mathrm{N} \\
\mathrm{O} .\end{array}$ & $\begin{array}{c}\text { Subjek } \\
\text { Coba }\end{array}$ & $\begin{array}{c}\text { Skor } \\
\text { Maksi } \\
\text { mal }\end{array}$ & $\begin{array}{c}\text { Hasil } \\
\text { Penila } \\
\text { ian }\end{array}$ & $\begin{array}{c}\text { Persen } \\
\text { tase } \\
(\%)\end{array}$ & $\begin{array}{c}\text { Ketera } \\
\text { ngan }\end{array}$ \\
\hline 1. & $\begin{array}{l}\text { Ahli } \\
\text { materi } \\
\text { pembela } \\
\text { jaran }\end{array}$ & 56 & 47 & 83,93 & Valid \\
\hline 2. & $\begin{array}{l}\text { Ahli } \\
\text { media } \\
\text { pembela } \\
\text { jaran }\end{array}$ & 68 & 66 & 97,05 & Valid \\
\hline 3. & $\begin{array}{l}\text { Uji } \\
\text { perorang } \\
\text { an }\end{array}$ & 180 & 149 & 82,78 & Valid \\
\hline 4. & $\begin{array}{l}\text { Uji } \\
\text { kelompo } \\
\text { k kecil }\end{array}$ & 540 & 444 & 82,22 & Valid \\
\hline 5. & $\begin{array}{l}\text { Uji } \\
\text { lapangan }\end{array}$ & 1920 & 1655 & 86,19 & Valid \\
\hline \multicolumn{2}{|c|}{ JUMLAH } & 2764 & 2361 & 86,43 & Valid \\
\hline
\end{tabular}

\section{Hasil Ketercapaian Domain STS}

Ketercapaian mobile learning mata pelajaran biologi berbasis STS diamati dari lima domain. Penilaian ini dilakukan saat siswa melakukan diskusi grup secara online. Diskusi online ini diikuti oleh 16 siswa. Hasil analisis data ketercapaian domain STS menunjukkan persentase sebesar 92,41\%. Berdasarkan data yang diperoleh dari ketercapaian domain STS, 
dapat dianalisis bahwa: (1) domain konsep, seluruh siswa dapat memberikan penjelasan ilmiah terkait topik yang dibahas; (2) domain proses, keterampilan proses sains yang dapat dicapai oleh seluruh siswa terdapat pada keterampilan komunikasi. Sedangkan untuk keterampilan observasi, klasifikasi dan menyusun hipotesis masih terdapat 2-3 siswa yang belum menguasai; (3) domain kreativitas, terdapat 2-3 yang belum mampu mengeluarkan ide/gagasan maupun menawarkan alternatif pemecahan masalah; (4) domain sikap, terdapat 1-2 orang siswa yang kurang menghargai pendapat orang lain, belum bisa mengontrol emosi saat diskusi sedang berlangsung, dan belum mampu membuat keputusan untuk penyelesaian masalah; dan (5) domain aplikasi yang dimaksud disini adalah aplikasi tahap awal, artinya tidak sampai diteliti ketika siswa terjun dalam masyarkat. Untuk domain ini, seluruh siswa dapat mencapai aplikasi tahap awal.

\section{Tes Hasil Belajar}

Tes hasil belajar dilakukan kepada 32 siswa dengan bentuk tes obyektif pilihan ganda. Dari 32 siswa, sebanyak 28 siswa tuntas memenuhi KKM (75), sedangkan 4 siswa belum belum mencapai KKM. Hasil analisis data tes hasil belajar menunjukkan persentase sebesar 90,32\%. Produk pengembangan mobile learning berbasis STS termasuk kategori efektif untuk mencapai tujujan pembelajaran.

\section{PEMBAHASAN}

\section{Kajian Produk yang Telah Dievisi}

Pengembangan produk mobile learning berbasis Science, Technology, and Society (STS) didasari oleh konsep mobile learning bahwa belajar dapat dilakukan kapanpun dan dimanapun. Bukan hanya kemudahan dalam belajar, namun belajar juga harus bermakna (Ausubel, 1963). Pembelajaran bermakna merupakan suatu proses mengaitkan informasi baru pada konsep-konsep relevan yang terdapat dalam struktur kognitif seseorang. Pengetahuan ini awal atau disebut pengetahuan superordinate (Degeng, 2013: 77) bertindak sebagai 'kerangka cantolan' bagi pengetahuan baru yang akan dipelajari.

Fokus pembelajaran yang bermakna sesuai dengan pandangan bahwa belajar adalah mengkonstruksi pengetahuan .... yang didalamnya terdapat proses-proses kognitif yang digunakan siswa secara aktif (Anderson \& Krathwohl, 2015: 98). Agar terjadi proses kognitif ketika seseorang belajar, diperlukan sebuah alat yang mendukung, membimbing, dan memperluas proses berpikir siswa. Alat ini disebut dengan alat kognitif (cognitive tools). Jonassen \& Mayes (1981) mendefinisikan "cognitive tools are computer-based devices and environments that extend the thinking processes of learners. These are tools that are used to engage learners in meaningful cognitive processing of information".

Model pembelajaran STS juga didasari oleh teori konstruktivisme dimana siswa harus membangun pemahaman mereka sendiri. Interaksi sosial dalam bentuk diskusi, perdebatan, dan argumen memainkan peran penting dalam membentuk pemahaman. Model pembelajaran STS juga dapat melatih kepedulian siswa terhadap lingkungan di sekitarnya, sebagaimana yang diungkapkan oleh Poedjiadi (2010: 123) bahwa tujuan model pembelajaran STS adalah untuk membentuk individu yang memiliki literasi sains dan teknologi serta memiliki kepedulian terhadap masalah masyarakat dan lingkungannya.

Mobile learning yang menggunakan model pembelajaran STS dapat dipandang sebagai alat kognitif, sebab konten dan kegiatan dalam mobile learning mengarah pada (1) kategorikategori dalam dimensi proses kognitif, (2) bersifat konstruktivistik, dan (3) dikendalikan oleh siswa sendiri. Pertama, mobile learning memiliki dimensi proses kognitif. Misalnya pada kategori memahami (C2) dan proses kognitif mencontohkan, siswa diharapkan dapat memberi contoh interaksi yang bersifat 
komensalisme dalam ekosistem. Kedua, bersifat konstruktivistik. Mobile learning memfasilitasi proses membangun pengetahuan oleh siswa melalui kegiatan diskusi online dengan menggunakan model STS. Ketiga, dikendalikan oleh siswa sendiri. Dengan mobile learning, kontrol belajar terletak pada siswa itu sendiri. Siswa bebas untuk menentukan waktu, kecepatan, dan gaya belajar masingmasing.

Produk mobile learning berbasis STS secara khusus berisi materi ekosistem dan pencemaran lingkungan. Produk ini berbentuk aplikasi dengan format apk (application package file) yang dapat digunakan pada smartphone maupun tablet minimal versi jellybean. Produk ini terpatri dengan Adobe AIR, sehingga untuk menjalankan aplikasi ini harus terlebih dahulu menginstal Adobe AIR. Aplikasi ini dapat dijalankan secara offline, kecuali jika ingin masuk ke menu diskusi membutuhkan koneksi internet.

\section{Kajian Konsep Desain Produk Pengembangan}

Konsep desain utama produk mobile learning berbasis STS adalah minimalis dengan perpaduan background yang didominasi warna putih dan hijau. Penggunaan warna putih dimaksudkan agar pengguna dapat terfokus, dan tulisan maupun gambar dapat terbaca dengan jelas. Sedangkan penggunaan warna hijau berfungsi sebagai header dari setiap sub materi. Penggunaan warna hijau juga dipilih karena materi yang dikembangkan adalah materi biologi yang sangat identik dengan warna hijau.

Jenis huruf yang digunakan dalam sajian materi adalah Arial dan Rockwell. Untuk judul sub materi menggunakan jenis huruf Arial 18, sedangakan untuk isi materi menggunakan jenis huruf Rockwell 16. Meskipun ukuran ini relatif besar jika digunakan untuk jenis huruf bahan ajar cetak, namun dalam aplikasi Adobe Flash Professional CS 6 untuk android ukuran ini adalah standar. Pewarnaan huruf harus kontras dengan warna latarnya agar terbaca dengan jelas dan supaya menarik perhatian siswa terhadap materi yang disajikan. Warna yang digunakan untuk sajian materi adalah hitam dengan hightlight warna hijau tua untuk memberi penekanan pada istilahistilah atau kata-kata yang penting.

\section{Sajian Materi Produk Pengembangan}

Produk mobile learning berbasis STS terdiri dari empat menu utama, yakni tujuan pembelajaran, materi, video, dan diskusi, serta dua menu pendukung yakni petunjuk pemanfaatan dan pengembang. Pertama, pencantuman tujuan pembelajaran dapat memberikan arahan bagi pengguna mengenai apa yang akan dicapai setelah belajar dengan media mobile learning. Kedua, menu materi mencakup materi ekosistem dan pencemaran lingkungan. Penyajian materi dalam produk mengandung unsur dan prinsip-prinsip multimedia.

Ketiga, menu video berisi video tentang pencemaran lingkungan. Video ini bertujuan sebagai invitasi bagi siswa untuk membahas materi/permasalahan yang dapat dibahas pada menu keempat yaitu menu diskusi. Menu diskusi mempersiapkan siswa menuju ruang diskusi secara online. Kelima, petunjuk pemanfaatan merupakan arahan bagi pengguna untuk menggunakan aplikasi. Pada menu ini dijabarkan fungsifungsi dari setiap tombol yang terdapat dalam produk. Keenam, menu pengembang yang bertujuan memberi informasi kepada pengguna tentang identitas pengembang produk.

\section{Sintaks Pembelajaran Mobile Learning Mata Pelajaran Biologi Berbasis STS}

Pemanfaatan mobile learning mata pelajaran biologi berbasis STS dalam pembelajaran dikelompokkan menjadi dua jenis kegiatan, yaitu kegiatan tatap muka di dalam kelas dan kegiatan diskusi online di luar kelas. Pertemuan pertama, dimulai dengan kegiatan pembelajaran tatap muka di dalam kelas. Pada pertemuan ini, siswa 
membahas materi tentang ekosistem yang terdapat dalam aplikasi mobile learning. Pada kegiatan ini, siswa dibagi menjadi empat kelompok, masing-masing kelompok mempelajari satu macam daur biogeokimia. Perwakilan kelompok melakukan presentasi di depan kelas. Diakhir pembelajaran, siswa diberikan kesempatan untuk bertanya serta penarikan kesimpulan.

Jeda waktu antara pertemuan pertama dan kedua di kelas, dimanfaatkan untuk melaksanakan diskusi online. Diskusi online dilaksanakan sebanyak dua kali. Diskusi online ini menerapkan model Science, Technology and Society (STS). Dalam diskusi online ini, siswa juga dinilai dengan menggunakan rubrik penilaian domain STS. Guru berperan sebagai administrator grup untuk memandu jalannya diskusi. Dalam diskusi ini, siswa wajib berpatisipasi dengan cara menyampaikan pendapatnya, maupun mengomentari pendapat siswa yang lain. Hasil dari diskusi online ini akan dibahas pada pertemuan kelas.

Pertemuan kedua pada kelas tatap muka dilanjutkan dengan membahas tema yang telah didiskusikan dalam diskusi online. Setiap kelompok wajib menyampaikan hasil diskusinya di depan kelas. Hasil diskusi dari satu kelompok dapat melengkapi hasil diskusi dari kelompok yang lain. Di akhir pembelajaran, guru bersama-sama siswa menarik kesimpulan dari tema yang dibahas dan manfaat yang dapat dipetik dari kegiatan pembelajaran. Untuk memperjelas alur kegiatan yang dilakukan selama penerapan pembelajaran mobile learning mata pelajaran biologi berbasis STS, peneliti membuat sebuah diagram alur pembelajaran sebagai berikut.

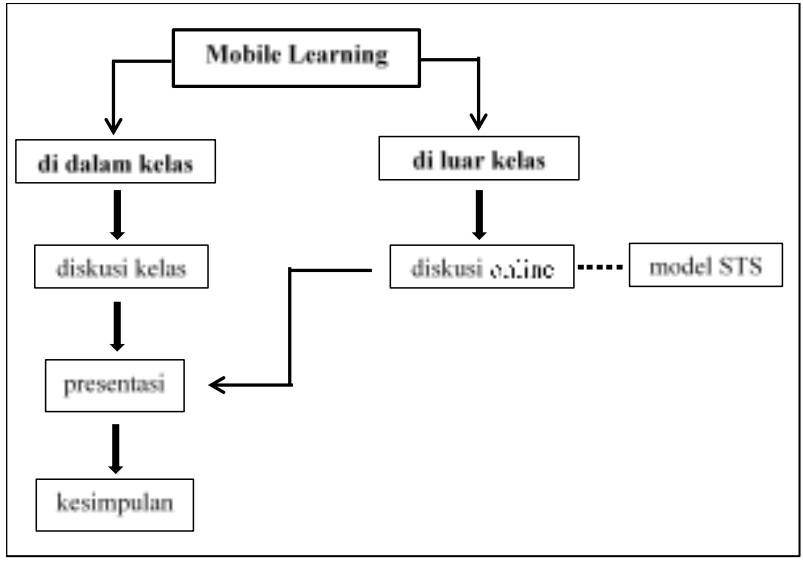

Gambar 1. Alur pembelajaran mobile learning mata pelajaran biologi berbasis STS

\section{Kelebihan dan Kelemahan Produk}

Produk mobile learning berbasis STS ini tentu memiliki dua sisi, yaitu kelebihan dan kelemahan. Adapun kelebihan dari produk mobile learning berbasis STS antara lain: (a) produk yang dikembangakan bersifat interaktif; (b) produk yang dikembangakan dilengkapi dengan ilustrasi dan contoh-contoh visualiasasi yang membantu pengguna memahami materi; (c) penyajian materi terstruktur; (d) terdapat menu diskusi yang membantu pengguna untuk berbagi pengetahuan, berinteraksi dan berkomunikasi dengan pengguna yang lain; (e) distribusi produk ini sangat mudah karena berformat APK dan dapat diperoleh secara gratis; (f) pembelajaran STS dapat mengasah kemampuan berpikir siswa serta belajar mengambil peran sebagai anggota masyarakat.

Sedangkan kelemahan yang terdapat pada produk mobile learning berbasis STS antara lain: (a) produk ini bergantung pada ukuran layar dan resolusi smartphone atau tablet pengguna yang dapat mengakibatkan berubahnya ukuran tampilan; (b) produk yang dihasilkan tidak adaptif karena berupa aplikasi offline, dan konten tidak dapat ter-update; (c) menu diskusi online, menggunakan source link sehingga anggota diskusi akan terakumulasi dengan pengguna sebelumnnya. Hal ini dapat diantisipasi 
dengan selalu meng-update source linknya; dan (d) keberhasilan pembelajaran STS sangat bergantung pada kompetensi guru terutama dalam penguasaan konten, problem solving dan hubungan interpersonal.

\section{KESIMPULAN DAN SARAN}

Model pembelajaran Science, Technology and Society (STS) dapat digunakan untuk melatih kemampuan siswa dalam berinteraksi sosial, melatih kemampuan berpikir, turut mengemukakan pendapat serta pemecahan masalahmasalah sains dan sosial yang sedang berkembang. Mobile learning adalah cara belajar dengan menggunakan perangkat mobile untuk mengakses sumber-sumber belajar, memiliki konektivitas dengan guru atau siswa yang lain, mempelajari konten pembelajaran tanpa terkendala keterbatasan jarak, ruang dan waktu. Mobile learning berbasis STS dapat memfasilitasi belajar dimana saja tanpa kehilangan esensi pembelajaran STS.

Berdasarkan tanggapan hasil angket dan wawancara oleh pengembang, terdapat beberapa saran untuk pengembangan produk lebih lanjut meliputi: (a) desain tampilan dibuat lebih menarik dengan perpaduan warna yang kontras agar siswa lebih antusias menggunakan produk mobile learning; (b) produk mobile learning berbasis STS ini dirancang dengan menggunakan fungsi scrolling untuk melanjutkan materi dalam satu halaman. Untuk pengembangan produk selanjutnya disarankan mengembangkan aplikasi yang menggunakan fungsi swipe; (c) aplikasi yang digunakan untuk menu diskusi online merupakan aplikasi yang terpisah dari mobile learning. Untuk pengembangan lebih lanjut, disarankan membuat sebuah aplikasi yang memenuhi fungsi keduanya; (d) pembelajaran STS benar-benar dirancang untuk diterapkan dalam waktu yang lama, sehingga dapat diobservasi sampai tahap aplikasi di masyarakat; dan (e) cakupan materi dalam produk ini terbatas pada materi ekosistem dan pencemaran lingkungan, untuk itu perlu dilakukan pengembangan untuk materi pelajaran yang lain.

\section{DAFTAR PUSTAKA}

Akcay, H \& Yager, R. E. 2010. The Impact of a Science/Technology/ Society Teaching Approach on Student Learning in Five Domains. J Sci Educ Technol (2010) 19:602611 DOI 10.1007/s10956-0109226-7.

Ausubel, D. P. 1963. The Psychology of Meaningful Verbal Learning. New York: Grune \& Stratton.

Anderson, L. W. \& Krathwohl, D. R. Tanpa tahun. Kerangka Landasan untuk Pembelajaran, Pengajaran, dan Asesmen. Terjemahan oleh Agung Prihantoro. 2015. Yogyakarta: Pustaka Pelajar.

Degeng, I.N.S. 2013. Ilmu Pembelajaran: Klasifikasi Variabel untuk Pengembangan Teori dan Penelitian. Bandung: Aras Media.

Jonassen, D. H. \& Mayes, J. T. 1981. Cognitive Tools for Learning. NATO ASI series, Series F: Computer and Systems Science, Vol. 81.

King, K. P. 2009. Examination of the Science-Technology-Society Approach to the Curriculum, (Online), http://www.cedu.niu.edu/scied/cour ses/ciee344/course_files_king/sts_r eading.htm, diakses 22 Desember 2016. 
Munir. 2013. Multimedia: Konsep \& Aplikasi dalam Pendidikan. Bandung: Alfabeta.

Mayer, R. E. 2009. Multimedia Learning: Prinsip-Prinsip dan Aplikasi. Yogyakarta: Pustaka Belajar.

Poedjiadi, A. 2010. Sains Teknologi Masyarakat: Model Pembelajaran Kontekstual Bermuatan Nilai. Bandung: Remaja Rosdakarya.

Smaldino, S.E., Russel, J. D., Heinich, R. \& Molenda, M. 2004. Instructional Technology and Media for Learning. Ohio: Prentice Hall.
Ulfa, S. 2013. Mobile Technology Integration into Teaching and Learaning. IEEESE International Journal of Science and Technology (IJSTE), 2 (1): 1-7.

Yager, R. E. 1992. The Status of ScienceTechnology-Society Reform Efforts Around the World. ICASE Yearbook.

Ziman, J. 1980. Teaching and learning about Science and Society. Cambridge, MA: Cambridge University Press. 